\title{
STRATEGI MENDONGENG KREATIF, CERDAS, DAN EDUTAIMEN
}

\author{
Yunus Abidin \\ (Dosen UPI Kampus Cibiru)
}

\begin{abstract}
Abstrak
Upaya memberikan pendidikan dini kepada anak pada prinsipnya dilakukan dalam tiga cara yakni bermain, bercerita, dan berbuatBermain dipandang sebagai cara paling tepat mengembangkan potensi anak sebab bermain mampu mengembangkan seluruh dimensi perkembangan anak.Cara kedua yang biasanya dilakukan untuk mengembangkan potensi anak adalah melalui bercerita.Berbuat adalah pola pendidikan anak usia dini yang juga sering dilakukan untuk membentuk jadi diri anak. Dari ketiga pola pendidikan bagi anak usia dini di atas, bercerita merupakan pola pendidikan yang mulai banyak ditinggalkan. Dalam lingkungan keluarga, bercerita telah tergeser posisinya dengan sajian acara televisi, sehingga banyak pula anak yang akhirnya terlelap di depan televisi. Bertemali dengan kenyataan ini, kegiatan mendongeng harus dilakukan dengan berbasis pada konsep mendongeng yang kreatif, cerdas, dan edutaimen. Pendongeng kreatif adalah pendongeng yang mampu mengkreasi kegiatan mendongeng menjadi kegiatan yang menarik dan berdaya guna bagi perkembangan anak.Pendongeng yang cerdas adalah pendongeng yang mampu memaksimalkan kegiatan mendongeng bagi pengembangan seluruh aspek perkembangan anak. Pendongeng yang memiliki jiwa edutaimen adalah pendongeng yang mampu menyajikan dongeng selayaknya sarana hiburan yang mendidik bagi anak.
\end{abstract}

Kata Kunci: Strategi Mendongeng, Kreatif, Cerdas, dan Edutaimen

\section{A. PENDAhuluan}

Pendidikan usia dini diyakini memiliki makna yang sangat penting bagi tumbuh kembang anak sehingga anak akan mampu meningkat kualitasnya di masa yang akan datang. Sejalan dengan keyakinan ini, upaya mendidik anak usia dini sedang menjadi fenomena utama yang terjadi di Indonesia. Hal ini ditandai dengan semakin banyaknya lembaga-lembaga PAUD, semakin menariknya program pendidikan PAUD, dan semakin maraknya buku-buku PAUD di pasaran. Bertemali dengan kondisi ini, secercah harapan muncul bahwa ke depan kualitas 
sumber daya manusia Indonesia akan mampu sejajar dengan bangsa-bangsa lain di dunia.

Upaya memberikan pendidikan dini kepada anak pada prinsipnya dilakukan dalam tiga cara yakni bermain, bercerita, dan berbuat (Abidin, 2009). Bermain dipandang sebagai cara paling tepat mengembangkan potensi anak sebab bermain mampu mengembangkan seluruh dimensi perkembangan anak. Bermain juga adalah dunia anak sehingga anak akan termotivasi untuk bermain. Ketika anak bermain, hampir tidak ada paksaan dalam dirinya untuk melakukan peran apapun selama permainan dilakukan. Dalam pandangan penulis bermain dalam dimensi ini bukan hanya bermain dalam kegiatan fisik, melainkan pula mencakup bermain imajinasi, semisal anak suka bicara sendiri. Kenyataan ini mendorong dijadikannya bermain sebagai sentral kurikulum PAUD.

Cara kedua yang biasanya dilakukan untuk mengembangkan potensi anak adalah melalui bercerita. Kegiatan bercerita sebenarnya bukan merupakan sebuah pola baru dalam mendidik anak usia dini. Kegiatan ini telah dilakukan sejak zaman dahulu dan telah menjadi kebiasaan orang tua untuk mengantarkan anakanaknya tidur. Kegiatan bercerita yang demikian, selain mendekatkan orang tua dan anak juga diyakini akan mampu mengembangkan karakter baik pada diri anak sejalan dengan isi cerita yang disampaikannya kepada si anak.

Berbuat adalah pola pendidikan anak usia dini yang juga sering dilakukan untuk membentuk jadi diri anak. Berbuat dalam posisi ini tidaklah sama dengan bekerja dan tidaklah pula sama dengan bermain. Yang dimaksud berbuat adalah pola pendidikan anak usia dini yang dilakukan orang tua agar anaknya secara langsung melakukan berbagai kegiatan baik yang bertujuan untuk mengembangkan kebiasaan maupun mengembangkan dimensi sosial, moral, dan religius pada anak usia dini. Beberapa jenis pola pendidikan melalui berbuat ini misalnya anak dibiasakan mengucapkan salam, terima kasih, dan maaf. Contoh lain adalah anak dibiasakan untuk membantu temannya, memberikan sedekah kepada orang lain, dan melakukan berbagai kegiatan harian yang memang sebaiknya dilakukan anak seperti membereskan mainan, membersihkan kamar, dan merapikan tepat tidur. 
Bertemali dengan pola-pola dasar kegiatan pendidikan anak usia dini yang telah biasa dilakukan sejak zaman dahulu tersebut, program pendidikan anak pada lembaga PAUD pun masih menerapkan ketiga pola pendidikan dasar anak tersebut sampai sekarang. Oleh sebab itu, program pembelajaran yang dilakukan pada lembaga PAUD pastilah berkenaan dengan tiga pola dasar tersebut, meskipun beberapa lembaga PAUD yang ada telah pula menambahkan pola pendidikan menjadi lebih formal dengan memberikan muatan membaca, menulis, dan berhitung pada peserta didiknya.

Dari ketiga pola pendidikan bagi anak usia dini di atas, bercerita merupakan pola pendidikan yang mulai banyak ditinggalkan. Dalam lingkungan keluarga, bercerita telah tergeser posisinya dengan sajian acara televisi, sehingga banyak pula anak yang akhirnya terlelap di depan televisi. Acara temu kangen keluarga yang dulu kental dengan acara mendongeng yang dilakukan kakek terhadap cucunya pun sudah mulai susah ditemukan. Yang banyak terjadi adalah kegiatan sebaliknya, yakni cucu memeragakan kemampuannya memainkan berbagai alat modern (semisal telepon genggam, komputer, i-pad, tablet, dan sejenisnya) yang telah dikuasainya. Kondisi terbengong justru dialami si kakek karena memang dia tidak mampu memainkan berbagai alat modern tersebut.

Kondisi mulai ditinggalkannya kegiatan bercerita dalam mendidik anak usia dini juga terjadi di lingkungan lembaga PAUD. Berbagai pelatihan yang muncul bagi para guru dalam mengembangkan kemampuan mendidik anak usia dini sudah mulai bergeser ke arah kemampuan praktik eksperimen. Bahkan yang lebih tragis, kegiatan pembinaan profesi formal bagi guru anak usia dini semacam PLPG pun lebih banyak mengarahkan para guru untuk senantiasa menciptakan kegiatan pembelajaran dengan berbasis kegiatan eksperimen. Kondisi semacam ini semakin memosisikan mendongeng pada sudut gelap yang lama kelamaan akan dilupakan.

Hal lain yang mendorong ditinggalkannya pola mendidik anak melalui kegiatan mendongeng adalah bahwa kegiatan mendongeng sudah dipandang sebagai kegiatan monoton, basi, dan tidak menyenangkan bagi anak. Pandangan ini semakin diperburuk dengan lemahnya kompetensi guru dalam mendongeng. 
Lemahnya kompetensi ini ditunjang pula oleh miskinnya upaya para guru untuk meningkatkan kemampuannya dalam mendongeng. Bahkan pada lembaga formal pendidikan guru anak usia dini pun, kompetensi mendongeng bukan menjadi kompetensi utama yang harus dimiliki guru PAUD, sebab kompetensi utama yang harus dikuasai lebih ditekankan pada aspek administratif pembelajaran. Melihat kenyataan ini wajarlah jika para pendidikan anak usia dini yang relatif masih muda dan baru lulus pun kurang memiliki kemahiran dan mendongeng.

Bertolak dari kenyataan di atas, muncul sebuah ketertarikan untuk membahas ihwal mendongeng. Pembahasan ini akan diarahkan pada upaya menempatkan kembali mendongeng pada posisi sentralnya dalam pendidikan anak usia dini. Guna mencapai tujuan tersebut, tentu saja diperlukan berbagai upaya yang tepat.

\section{B. MENDONGENG DAN PERKEMBANGAN ANAK}

Mendongeng dipandang memiliki beberapa keterhubungan dengan perkembangan anak usia dini. Hal inilah yang kemudian menjadikan mendongeng dijadikan salah satu pola pendidikan anak usia dini. Banyak ahli telah mengemukakan fungsi mendongeng bagi perkembangan anak. Beberapa fungsi penting mendongeng bagi perkembangan anak usia dini tersebut dikemukakan Musfiroh (2008); Majid (2005); dan Freeman (2010) sebagai berikut.

\section{Mengembangkan kesadaran moral bagi anak}

Dongeng adalah cerita fiksi yang disusun dengan tujuan utama sebagai media transfer moral. Data pandangan ilmu sastra, dongeng sebenarnya merupakan karya sastra klasik yang tidak diketahui siapa penulisnya. Kelahiran dongeng selalu dikaitkan dengan motif-motif cerita tertentu yang pada ujungnya motif-motif tersebut akan berisikan sejumlah nilai dan moral baik bagi para pendengarnya. Sejalan dengan peruntukannya tersebut sebuah dongeng senantiasa berakhir dengan gembira, yakni tokoh baik akan selalu menang terhadap tokoh jahat. Sejalan dengan hal ini, wajar saja dongeng akan memberikan sejumlah masukan moral bagi anak usia dini. Lebih jauh Elder dan Holyan (2010) 
memandang cerita akan pula membentuk kesadaran akan nilai, norma, dan moral budaya.

\section{Mengembangkan imajinasi anak}

Dongeng merupakan karya fantasi yang sifatnya imajinatif walaupun di sisi lain juga memiliki sifat kebermanfaatan. Bertemali dengan sifat imajinatifnya yang sangat kuat, dongeng dapat digunakan untuk mengembangkan daya imajinasi siswa (Parkinson, 2011). Daya imajinasi sendiri diakui merupakan sesuatu yang sangat bermanfaat bagi pengembangan kreativitas bahkan kemampuan sains anak-anak. Hal ini sejalan dengan kenyataan bahwa sebagian besar ilmu pengetahuan besar yang ditemukan justru berangkat dari imajinasi yang tidak ilmiah dan bahkan tidak logis. Berkenaan dengan kekhawatiran beberapa orang tua tentang daya negatif imajinasi dongeng, hal ini sebenarnya tidak perlu terjadi sebab sebuah dongeng yang sesungguhnya pastilah berisi muatan-muatan moralyang positif.

\section{Mengembangkan kemahiran berbahasa anak}

Kemahiran berbahasa anak mencakup beberapa komponen penting yakni menyimak, berbicara, menulis, dan membaca. Dalam kaitannya dengan mendongeng, mendongeng dipandang memiliki potensi untuk digunakan bagi pengembangan kemahiran menyimak dan berbicara siswa. Melalui mendongeng, anak akan dilatih berkonsentrasi selama menyimak dan lebih lanjut akan dirangsang untuk berbicara mengemukakan berbagai hal yang berhasil anak simak. Bertemali dengan kondisi ini, kegiatan mendongeng dapat dipilih guru agar anak minimalnya memiliki daya konsentrasi, daya paham, dan daya kreatif berbicara.

Dalam kaitannya dengan kemampuan pramembaca, mendongeng juga dapat digunakan untuk merangsang anak mengenal buku-buku dongeng bergambar. Dalam hal ini mendongeng dapat dijadikan sebagai sumber utama dalam menumbuhkan minat prabaca anak dan lebih lanjut dapat dijadikan sarana membina kemampuan prabaca dan pramenulis bagi anak usia dini. 


\section{Mengembangkan Fisik Motorik Anak}

Mendongeng dipandang hampir tidak memiliki keterkaitan dengan perkembangan fisik motorik anak. Namun demikian, kegiatan kreatif mendongeng sebenarnya memiliki keterkaitan yang sangat erat dengan fisik motorik anak. Hal ini dapat dilakukan jika guru secara kreatif memadukan kegiatan mendongeng dengan kegiatan bermain peran atau kegiatan bermain lain pasca mendongeng. Berdasarkan hal ini bukan hal tidak mungkin jika mendongeng dapat juga digunakan secara kreatif untuk mengembangkan fisik motorik pada anak usia dini.

\section{Mengembangkan Keterampilan Sosial Emosional Anak}

Keterampilan sosial emosional merupakan salah satu standar perkembangan yang penting dipenuhi oleh anak usia dini. Keterampilan ini berhubungan erat dengan kontrol diri, motivasi, sikap, percaya diri, empati, sosial, kerja sama, dan berbagai keterampilan sosial emosional lainnya. Berkaitan dengan hal ini, mendongeng baik dari segi isi maupun segi tindak lanjut kreatif sangat memungkinkan untuk digunakan untuk membangun dan memupuk keterampilan sosial emosional anak usia dini. Terhadap hal ini, Eades (2006) menyatakan bahwa dongeng dapat secara paripurna membentuk kesadaran sosial anak dan lebih lanjut mampu membina emosional anak

\section{Mengembangkan Kognitif Anak}

Isi sebuah dongeng tidak selalu hal yang bersifat imajinatif dan fiksional. Sebuah dongeng juga dapat berisi muatan sains, matematis, kewarganegaraan, maupun ilmu pengetahuan yang lain. Bertemali dengan isi dongeng yang diperdengarkan kepada anak usia dini ini, mendongeng sebenarnya akan efektif untuk digunakan mengembangkan aspek kognitif anak (Brand dan Danato, 2001). Bahkan bukan hal yang tidak mungkin kemampuan kognitif anak akan lebih berkembang melalui dongeng; konsep semacam ini dalam pandangan pembelajaran orang dewasa dikenal dengan istilah pembelajaran literasi berbasis konten area/ pembelajaran multiliterasi.

Sejalan dengan beberapa fungsi mendongeng di atas, kegiatan mendongeng seyogyanya masih harus tetap dijadikan sebagai sarana pengembangan anak usia dini. Dalam praktiknya nanti, kegiatan ini sangat 
mungkin untuk dipadukan dengan berbagai media baik media yang bersifat sederhana sampai media berbasis multimedia digital. Keberhasilan mendongeng dalam mengembangkan kemampuan anak usia dini kembali akan berpulang pada kreativitas dan daya juang guru membangun pendidikan anak usia dini yang harmonis, bermutu, dan bermartabat.

\section{PEMILIHAN BAHAN MENDONGENG}

Guna dapat mencapai tujuan mendongeng dalam rangka mengembangkan berbagai potensi anak usia dini, langkah pertama yang harus dilakukan oleh guru adalah memiliki dongeng. Proses pemilihan dongeng bertujuan agar diperoleh dongeng yang mampu membangkitkan kecintaan anak terhadap dongeng; meningkatkan pengetahuan ihwal isi dongeng yang bermanfaat bagi tumbuh kembang anak; dan dongeng yang merangsang kreativitas anak dalam berbagai dimensi perkembangannya.

Tujuan pertama memilih bahan mendongeng, dalam pandangan penulis merupakan hal yang sangat penting. Hal ini bertemali dengan kenyataan jika bahan mendongeng yang dipilih sudah bosan didengar anak atau tidak menarik bagi anak, maka proses pengemasannya pun akan lebih sulit. Hal yang lebih dikhawatirkan adalah anak tidak akan tertarik untuk menyimak dongeng tersebut lebih lanjut.

Tujuan kedua lebih diorientasikan pada isi dongeng. Isi dongeng yang baik haruslah bermuatan moral, pengetahuan, dan ilmu bagi anak. Melalui isi dongeng inilah nantinya anak diharapkan beroleh berbagai pengaruh positif sehingga akan mencapai berbagai kematangan sesuai dengan standar perkembangan mereka. Lebih lanjut isi dongeng juga haruslah sesuai dengan latar belakang anak agar isinya lebih mudah dipahami dan lebih bermakna bagi anak.

Isi sebuah dongeng juga hendaknya harus dipertimbangkan bagi kemungkinannya merangsang kreativitas anak. Dongeng yang baik hendaknya dapat ditindak lanjuti dengan berbagai aktivitas lanjutan yang bertemali dengan berbagai aspek perkembangan anak. Melalui isi dongeng yang demikian kejenuhan dan kemonotonan dalam mendongeng akan bisa dihindari. 
Berdasarkan tiga tujuan utama pemilihan bahan mendongeng di atas, sedikitnya ada tiga hal yang harus dijadikan landasan utama pemilihan bahan dongeng. Ketiga hal tersebut adalah sebagai berikut.

1. Isi.

Sebuah dongeng yang baik haruslah dongeng yang isinya mengajarkan karakter, moral, dan pengetahuan keilmuan. Aspek moral dalam dongeng hendaknya tidak menyiratkan kesan ambiguitas moralitas. Beberapa dongeng seperti ini banyak ditemui dalam konteks keindonesiaan, misalnya dongeng tentang kancil dan buaya, cerita anak yang membangkitkan dendam, dan cerita tentang ibu tiri yang kejam, dongeng semacam ini hendaknya tidak dipilih guru sebagai bahan ajar mendongeng.Selain itu dongeng yang baik adalah dongeng yang menarik bagi anak sehingga mereka akan termotivasi untuk menyimak dongeng tersebut. Berdasarkan hal ini dongeng yang dipilih hendaknya bukan dongeng yang sudah dikenal anak melainkan dongeng baru yang mungkin belum diketahui anak. Bertemali dengan hal ini, guru dituntut pula menyusun dongeng karyanya sendiri.

2. Struktur

Dongeng yang baik haruslah memiliki struktur yang jelas dan lengkap. Artinya, dongeng tersebut harus memiliki tokoh yang memiliki daya hidup, alur yang memiliki sifat plausibilitas, suspensi, surprise, dan misterius; seting yang mengandung metafora dan bukan hanya sekedar atmosfer cerita, dan sudut pandang yang jelas (Abidin, 2012). Selain itu, struktur dongeng secara utuh juga hendaknya dapat dikembangkan melalui kegiatan lain pasca mendongeng semisal bermain peran, games, ataupun kegiatan lain (Abidin, 2010).

3. Keterpahaman

Dongeng yang dipilih juga hendaknya dongeng yang dapat dipahami anak. Ini berarti dongeng haruslah sesuai dengan perkembangan psikologis anak dan sesuai pula dengan latar belakang anak. Dongeng-dongeng yang terlalu bersifat dewasa, jauh dari daya jangkau anak, dan memiliki jalan cerita yang 
terlalu kompleks hendaknya tidak dipilih untuk dijadikan bahan mendongeng bagi anak usia dini (Davies, 2007).

Sejalan dengan uraian di atas, guru memiliki peran penting dalam memilih dongeng yang akan dijadikan bahan pembelajaran. Selain itu dalam perspektif lain, guru seyogyanya mampu menyusun sendiri dongeng dan tidak hanya bergantung pada dongeng-dongeng yang sudah ditulis oleh orang lain. Dongengdongeng hasil rekaan guru dipandang lebih mudah di terapkan dalam proses pembelajaran sebab lebih dikuasai oleh guru selaku penulisnya.

\section{MENUJU MENDONGENG YANG KREATIF, CERDAS, DAN EDUTAIMEN}

Menjadi seorang pendongeng tidaklah sulit namun juga sebenarnya tidak juga mudah. Perlu beberapa upaya agar mampu menjadi pendongeng yang baik. Beberapa upaya dimaksud termasuk upaya pemilihan bahan yang tepat, pengelolaan kelas yang baik (Spaulding, 2011), penyusunan program lanjutan yang motivatif, dan latihan kecil menjadi pendongeng. Bertemali dengan hal ini, penulis menyungguhkan konsep mendongeng yang kreatif, cerdas, dan edutaimen.

Pendongeng kreatif adalah pendongeng yang mampu mengkreasi kegiatan mendongeng menjadi kegiatan yang menarik dan berdaya guna bagi perkembangan anak. Sehubungan dengan hal ini, pendongeng kreatif hendaknya memperhatikan beberapa hal sebagai berikut.

1. Menguasai bahan yang akan didongengkan.

2. Memiliki kemampuan membaca ekspresif yang baik, meliputi nada, intonasi, jeda, dan pelafalan yang tepat.

3. Memiliki kemampuan mengekspresikan karakter dalam dongeng, seting dalam dongeng, dan memosisikan diri dalam dongeng yang dibacakannya.

4. Memiliki kemampuan memerankan tokoh dalam dongeng untuk memperkuat daya simak siswa.

5. Mendayagunakan media yang tepat selama mendongeng.

6. Memberikan kejutan-kejutan bagi siswa selama mendongeng.

Menilik beberapa hal di atas, upaya menjadi pendongeng yang kreatif senantiasa berhubungan dengan bahan, aksi, dan improvisasi. Mendongeng 
bukanlah kegiatan hanya sekadar duduk di tengahlingkaran siswa, melainkan bermonolog dalam pentas teater. Oleh sebab itulah pendongeng kreatif harus pula cerdas dan memiliki daya edutaimen yang baik.

Pendongeng yang cerdas adalah pendongeng yang mampu memaksimalkan kegiatan mendongeng bagi pengembangan seluruh aspek perkembangan anak. Dalam hal ini, mendongeng tidak hanya ditujukan untuk mengembangkan satu atau dua aspek saja, melainkan pada seluruh aspek atau minimalnya beberapa aspek perkembangan anak. Bertemali dengan hal ini, hal-hal yang harus diperhatikan untuk menjadi pendongeng yang cerdas adalah sebagai berikut.

1. Ciptakan kegiatan mendongeng yang menarik bagi siswa dengan mengolaborasikan kegiatan mendongeng dengan berbagai kegiatan lain, seperti bermain peran, permainan interaktif, dan eksperimen sains.

2. Libatkan anak selama mendongeng baik hanya disapa, ikut memerankan tokoh, sampai pelibatan lain yang menuntut siswa melengkapi dongeng.

3. Awali kegiatan mendongeng dengan kegiatan apersepsi yang menarik, menumbuhkan rasa ingin tahu anak, dan memberitahukan jenis-jenis keterlibatan anak selama kegiatan mendongeng.

4. Akhiri kegiatan mendongeng dengan memberikan penguatan terhadap nilai, moral, dan pengetahuan yang terkandung dongeng.

Sejalan dengan empat hal di atas, pendongeng cerdas bukanlah pendongeng yang hanya memandang kegiatan mendongeng sebagai kegiatan tunggal, melainkan kegiatan yang dapat dikreasi secara cerdas dengan berbagai aktivitas lainnya. Menilik kondisi ini menjadi pendongeng yang cerdas haruslah senantiasa memikirkan berbagai kemungkinan pemaduan kegiatan mendongeng dengan kegiatan lain yang relevan selama proses pembelajaran berlangsung.

Pendongeng yang memiliki jiwa edutaimen adalah pendongeng yang mampu menyajikan dongeng selayaknya sarana hiburan yang mendidik bagi anak. Konsep mendongeng edutaimen harus mampu meningkatkan keasyikan anak selama kegiatan mendongeng. Lebih lanjut, anak harus merasa bahwa kegiatan ini bukan hanya kerja guru, melainkan kerja anak, sehingga guru dipandang sebagai 
sutradara dan anak adalah aktor. Berkenaan dengan konsepsi ini, berikut dikemukakan beberapa hal yang harus diperhatikan guna mampu menjadi pendongeng yang edutaimen.

1. Tatalah lingkungan kelas untuk mendongeng dengan seting yang sesuai dengan isi dongeng sehingga siswa akan lebih hidup dengan suasana yang dibangun.

2. Siapkan lokasi peran, kostum, dan peralatan lainnya yang akan digunakan anak berkreasi selama kegiatan mendongeng.

3. Rekanlah kegiatan selama mendongeng walaupun hanya dengan menggunakan alat perekam sederhana.

4. Tontonlah kembali hasil rekaman tersebut bersama anak pada kesempatan lain, lakukan diskusi, dan perbaikan seperlunya; jika perlu rancanglah kegiatan lanjutan atas hasil kinerja pada saat mendongeng tersebut.

5. Rencanakan pemutaran hasil kegiatan pada seluruh kelas sehingga anak merasa memiliki rasa bangga atas hasil kegiatannya.

Demikianlah beberapa hal yang berkenaan dengan pendongeng yang edutaimen. Tentu saja tidaklah mudah melakukan seluruh kegiatan di atas. Di sini hal yang perlu dimiliki pertama adalah komitmen menjadi pendidikan anak usia dini yang profesional. Kreatif, cerdas, dan edutaimen sendiri sebenarnya merupakan konsep visioner dalam mewujudkan pengembangan kemampuan multiliterasi anak usia dini dalam memasuki usia desa yang penuh dengan kejutan dan perubahan.

\section{E. PENUTUP}

Mewujudkan kegiatan mendongeng yang multifungsi dalam konsep pendidikan anak usia dini memang memerlukan komitmen bersama antara guru, pihak sekolah, orang tua, dan anak. Hal ini menjadi syarat mutlak untuk mengembangkan pembelajaran yang lebih baik di masa yang akan datang. Kerja kerja, kerja cerdas, dan kerja ikhlas memang haruslah menjadi fondasi utama dalam mengembangkan mutu proses dan hasil pendidikan anak usia dini. Semoga 
kita tidak akan pernah berhenti berjuang; selalu semangat membentuk generasi emas anak bangsa. Amin.

\section{DAFTAR PUSTAKA}

Abidin, Y. (2009) Bermain: Penerapan Pendekatan BCCT dalam Gamitan PAUD. Bandung: Rizqi Press.

Abidin, Y. (ed.) (2010) Dimensi-Dimensi Pembelajaran dalam Pendidikan Anak Usia Dini. Bandung: Rizqi Press.

Abidin, Y. (2012) Prosa Fiksi dalam Multiperspektif. Bandung: HSAA Press.

Brand,

S.T.

dan Danato,J.M.(2001)StorytellinginEmergentLiteracyFosteringMultipleIntelli gences. Canada: Delmar Thomson Learning.

Davies, A. (2007) StorytellingintheClassroomEnhancing Oral andTraditionalSkillsfor Teachers. California: Paul Chapman Publishing.

Eades, J.M.F. (2006)ClassroomTales: UsingStorytellingtoBuildEmotional, Social andAcademicSkillsAcross The PrimaryCurriculum. London: Jessica Kingsley Publishers.

Elder, D. dan Holyan, R. (2010)Life LessonsthroughStorytellingChildren's Exploration of Ethics. Bloomington: Indiana University Press.

Freeman, J. (2010) UsingStorytelling, Creative Drama, andReader'sTheaterwith Children inGrades PreK-6. London: LibrariesUnlimited.

Majid, A.A.A. (2005) Mendidik dengan Cerita. Bandung: Rosda Karya.

Musfiroh, T. (2008) Memilih, Menyusun, dan Menyajikan Cerita untuk Anak Usia Dini. Yogyakarya: Tiara Wacana.

Parkinson, R. (2011)StorytellingandImagination:BeyondBasicLiteracy 8-14. New York: Routledge.

Spaulding,A.E.(2011) The Art of Storytelling: TellingTruthsthroughTellingStories. Toronto: The Scarecrow Press, Inc. 